\title{
Using the Seminar Format to Explore Pre-service Teachers' Argumentative Abilities in English as a Foreign Language'
}

\author{
El Uso del Seminario Socrático como Formato para \\ Explorar las Habilidades Argumentativas de Futuros \\ Docentes de Inglés como Lengua Extranjera
}

\author{
Pelusa Orellana ${ }^{2 *}$ \\ Universidad de los Andes, Chile
}

\begin{abstract}
The current study describes the introduction of seminar discussions in a literature course to track students' growth in argument production across the semester. Sixteen students enrolled in a required teacher education course were asked to plan and facilitate a 50-minute seminar discussion on a literary text, following the Paideia Seminar protocol. The course was taught in English, although the students' first language was Spanish. Over the course of the semester, I monitored students' progress in developing evidence-based coherent arguments and counterarguments. Pre-service teachers not only gained expertise as seminar facilitators, but their oral and written responses to seminar issues revealed an increase in more elaborated arguments, use of textual references, counterargument production, and overall sophisticated thinking.
\end{abstract}

Keywords: Argumentation, teacher education, Socratic dialogue, preservice teachers

1 Received: Dec. 15, 2014 / Accepted: April 13, 2015

2 porellan@uandes.cl 


\section{Resumen}

Este estudio describe el uso de discusiones socráticas en un curso de literatura en pregrado para hacer un seguimiento a la producción argumentativa de los estudiantes durante el semestre. Participaron dieciséis estudiantes de un programa de formación docente, quienes planificaron y lideraron un seminario de discusión de 50 minutos sobre un texto literario siguiendo el formato del seminario Paideia. Aunque la lengua materna de los estudiantes era el español, el curso de dictó en inglés. Durante el curso, se monitoreó el progreso de los estudiantes en relación al desarrollo de argumentos y contraargumentos coherentes. Los estudiantes no solo adquirieron experiencia como facilitadores del seminario sino que sus respuestas verbales y escritas a las temáticas discutidas revelaron un aumento en la habilidad para elaborar argumentos más elaborados, uso de referencias textuales, contraargumentos y una reflexión general más sofisticada.

Palabras clave: Argumentación, formación docente, discusión socrática, docentes en formación

\section{Resumo}

Este estudo descreve o uso de discussões socráticas em um curso de literatura em graduação para fazer um seguimento à produção argumentativa dos estudantes durante o semestre. Participaram dezesseis estudantes de um programa de formação docente, os quais planejaram e lideraram um seminário de discussão de 50 minutos sobre um texto literário seguindo o formato do seminário Paideia. Mesmo que a língua materna dos estudantes fosse o espanhol, o curso de foi ditado em inglês. Durante o curso, monitorou-se o progresso dos estudantes em relação ao desenvolvimento de argumentos e contra-argumentos coerentes. Os estudantes não só adquiriram experiência como facilitadores do seminário senão que suas respostas verbais e escritas em quanto às temáticas discutidas revelaram um aumento na habilidade para elaborar argumentos mais elaborados, uso de referências textuais, contra-argumentos e uma reflexão geral mais sofisticada.

Palavras chave: Argumentação, formação docente, discussão socrática, docentes em formação 


\section{Introduction}

rgumentation has become a topic of growing interest among
researchers over the past 30 years, and a much desired
educational objective (van Eemeren, Grootendorst \& Snoeck, 1996). Students who are able to develop higher cognitive abilities are more likely to perform better in school, pursue secondary education, and have access to better job opportunities (Kuhn and Udell, 2003; Mercer, 2011). Recent research has also shown that argumentative abilities can and must be taught. Students' acquisition of these skills is strongly dependent on having opportunities to practice argumentation (Gillies \& Khan, 2009), and on having teachers who model the use of good arguments in the classroom (Simon, Erduran, and Osborne, 2002). However, recent assessments and reports have highlighted the difficulties students show in both identifying and producing arguments (Kim, Anderson, Nguyen-Jahiel, \& Archodidiou, 2007; Means \& Voss, 1996, Reznitskaya, Anderson, \& Kuo, 2007). This difficulty has been attributed to the lack of authentic discussion contexts in which students can use argumentative skills. It has been observed that many discussion contexts continue to exhibit traditional recitation formats where no open-ended questions trigger argument production. The absence of actual systematic instruction, scaffolding, and modeling of effective argument construction prevents students from gaining the necessary competences to effectively engage in argumentation (Kuhn \& Udell, 2003; Lin, 2012; Rojas-Drummond \& Mercer, 2003).

Research evidence has also pointed out that explicit teaching and monitoring of argumentation skills takes place in late middle school and high school, and is often not addressed in the elementary grades (Lazarou, 2009; Kuhn, 2011). For example, it has been demonstrated that children can make an opinion and provide reasons for it quite early in their school lives (McCann, 1989), and can provide reasons to back up arguments at around fourth or fifth grade (Ferretti, Lewis, \& Andrews-Weckerly, 2009). More complex argument-related abilities, such as developing counterarguments may be more challenging and should probably be incorporated later in the curriculum (Leitao, 2003; Nussbaum \& Kardash, 2005).

We also know from research that teachers tend to replicate instructional practices they were exposed to as students (DarlingHammond, 2006). Therefore pre-service teachers, who never experienced authentic discussion or explicit argument-building strategies, seldom implement these practices in their own classrooms. The responsibility of ensuring that pre-service teachers develop these abilities and put them to practice is left to teacher education programs, 
particularly in the area of content knowledge and general pedagogical knowledge (Shulman, 1986).

One way to make pre-service teachers aware of the need to assist students in acquiring these strategies is creating instances in which they learn to observe and engage in quality arguments, ask questions that trigger discussion and reasoning while at the same time scaffold argument production. Seminar discussions are a suitable context for future teachers to engage in argumentation, to understand how to use discussions that foster reflection and divergent thinking, and for instructors to assess the quality of arguments.

\section{Literature Review}

\section{Argumentation and Dialogic Discussion}

Interest on argumentation stems from the belief that social interaction is the basis for individual thinking (Reznitskaya, Anderson, McNurlen, Nguyen-Jahiel, Archodidou, \& Kim, 2001; Cazden, 1988), and from the fact that argumentation is inherently a human activity (Voss \& Van Dyke, 2001). Proactive citizenship and social interaction are strongly linked to our ability to participate in discussions and debates about issues that affect our lives (Walzer, 2004). Such participation is enriched and becomes productive when we are capable of building sound and coherent arguments that rely on sensible data, and where argument components are feasible and well supported. An ample body of research indicates that student participation in discussion leads to better argumentation (Reznitskaya et al, 2001; Chinn, Anderson, \& Waggoner, 2001; Kim et al, 2007). It has also been observed that discussion settings facilitate the acquisition of more sophisticated argumentative strategies, as children tend to imitate certain argumentative practices they observe in other learners (Anderson, Nguyen-Jahiel, McNurlen, Archodidou, Kim, Reznitskaya, Tillmans, \& Gilbert, 2001; Nussbaum, 2002; Maloney \& Simon, 2006).

Unfortunately, dialogic discussion is far from being a habitual practice in many classroom settings (Carbonaro \& Gamoran, 2002). 54 For example, in a study where 48 high school social studies teachers were observed, Nystrand, Gamoran, and Carbonaro (2001) found that up to $90 \%$ of total instruction time did not include any discussions. Many claim that discussion has been left aside as a result of high-stakes testing requirements and reading programs in which teachers must follow a scripted routine, leaving no space for reflection on texts and their ideas (Allington, 2002; Noguera \& Cohen, 2006). On the other 
hand, teacher educators hold that there also seems to be a need for teachers to experience discussion as a way of teaching and as a way of learning, before they can actually feel confident about using it in their own classrooms (Rojas-Drummond \& Zaparta, 2004; Pedrosa, Silva, Moreira, \& Watts, 2012).

Onewouldexpect that dialogic discussioninstances in the classroom be like windows into students' thinking processes. Such instances help students analyze a topic in a non-threatening environment, and engage in conversations that go beyond literal messages or commonly accepted opinions. Researchers have identified the features that characterize such conversational contexts (e.g., Nystrand, Wu, Gamoran, Long, \& Zeiser, 2003; Goldstein, Crowell, \& Kuhn, 2009). Among these features are: the use of open-ended questions as conversation starters, student control and choice over discussion topic and turn taking, and the complexity and ambiguity of the topic being discussed. Examples of conversationrich and cognitively productive contexts are collaborative reasoning, Paideia seminars, literature circles, and instructional conversations.

A Paideia seminar is "a collaborative, intellectual dialogue facilitated with open- ended questions about a text" (Billings \& Roberts, 2006, p.1). In a Paideia seminar, learners collectively explore an artifact (literary document, artwork, musical piece, and math or science problem) and through discussion come to a more elaborate understanding of its meaning. Paideia seminars foster dialogue through more complex intellectual questions that often challenge students to go beyond literal meaning, and to build elaborate textual interpretations. Active dialogic participation not only leads students to read with understanding and move beyond surface meaning, but most of all, it allows students to think for themselves rather than replicate scripted answers (Haroutunian-Gordon, 1991; Nystrand, Gamoran, Kachur, \& Pendergast, 1997). In a Paideia seminar, participation and topic control are less restricted, so students can tailor the discussion more freely, while at the same time maintain intellectual rigor by having to provide textual evidence or use prior knowledge as support for their arguments. Similarly, in studies about the use of open-ended authentic questions (Nystrand et al., 2003; Chinn et al., 2001), researchers have observed that the overall quality of discourse increases when teachers use openended questions to guide discussion.

Theoretically, the frequent use of challenging questions in Paideia seminars should increment the production of high quality argumentation because they refer to ambiguous issues, address complex ideas in the text, and often require participants to face them from more than one perspective. When teachers use challenging open-ended questions, 
it is more likely that divergence of ideas should emerge. It is also more likely that, because not everyone agrees on a given aspect, more complex arguments and counterarguments are created. It seems reasonable to believe that, if the above-mentioned conditions occur in Paideia Seminars, they should facilitate the development of high quality argumentation.

\section{The Maieutic Frame as a Tool to Assess Argument Quantity and Quality}

The maieutic frame is a construct that I have created to describe the structure of the kind of talk that happens when students discuss texts guided by open-ended questions. The maieutic frame outlines the components within a portion of discourse occurring within a Paideia Seminar discussion. It allows us to divide a seminar discourse transcript into sections that contain those elements that make seminar dialogue maieutic. The notion of maieuticness derives from the Socratic idea of using dialogue, and particularly questions, to assist learners in bringing out meaning and understanding. I have borrowed the concept from the Socratic method, which is, precisely, maieutic in nature. Given that this is a new construct, existing research on classroom discussions about texts can provide a framework that can help us understand the importance of maieutic frames, particularly with regard to how it relates to argumentation.

I have also relied on the theory and research about discussion in general because Paideia seminars are one form of classroom discussion. Although classroom talk and discussions tend to be one of the most widely used pedagogical tools, not all discussions are instances of argument creation. The kinds of conversations that foster argumentation are usually built around open-ended questions that demand the use of textual or external references, and that lead students to interpret and explain ideas using their prior knowledge and experience. These argument-rich conversations exhibit inductive and exploratory talk in which participation is open and not structured by the teacher. What researchers have found out about the associations between classroom discussion and quantity and quality of argumentation is, largely, very similar to what maieutic frames are made of, and to what happens in a Paideia seminar. These findings can therefore contribute to interpreting and understanding maieutic frame presence in Paideia seminars.

Maieutic frames make the structure of the kind of talk that unfolds in a Paideia seminar visible. In a way, maieutic frames can be a window into students' thinking, because they allow us to observe how maieutic 
moments occur, in which students, with the adequate scaffold, can make meaning independently. If such maieutic moments emerge, students will have constructed their own understandings of the text without replicating the teacher's or the author's words.

A maieutic frame identifies the elements of a seminar that provide the necessary scaffolding for students to construct arguments as they examine a text. For example, maieutic frames may reveal the extent to which students use textual references to explain or interpret a text, or the extent to which prior knowledge is used to make meaning, or understand ideas. Similarly, a maieutic frame may show what triggers divergent thinking or new understanding, how disagreements about interpretations are solved or unsolved, or which questions trigger more argumentation building, and which ones do not.

By looking at the ways in which maieutic frames unfold, teachers might plan seminars that facilitate the emergence of maieutic moments in which participants, referencing the text and relying on their knowledge and experience, can acquire an enriched understanding collaboratively. Knowing which aspects of the seminar to target, teachers can develop challenging questions that will gauge discussion in such a way that dialogue will be divergent and argumentative.

\section{Methodology}

\section{Research Design}

The study uses using both qualitative and quantitative data and attemps to answer the following questions: 1) Is the degree of maieutic frame present associated with quantity and quality of argumentation in a Paideia Seminar? And 2) As students gain more expertise in Paideia Seminar facilitation and participation, is there an increase in the quantity and quality of their arguments?

\section{Context and Participants}

Sixteen female pre-service teachers enrolled in a literature course participated in the study. The course is a requirement of the bilingual elementary teaching program at a Chilean university. The students' level of English is intermediate. The course is designed for students to understand the structure of narrative fiction, and to develop critical understandings of various narrative works. For the study, each participant was asked to choose one of the selected readings, to plan and facilitate a 50-minute Paideia seminar. Pre-service teachers were 
already familiar with seminar discussions as participants, but not as facilitators, so I taught and modeled seminar planning and facilitation. Participants were asked to complete a standard seminar plan format, and I provided feedback on their seminar questions prior to facilitation, as well as immediately following the seminar discussion. At the end of the semester, students were asked to assess the discussions in terms of its impact on their learning and as a teaching strategy to be used by them later as in-service teachers.

\section{Data Collection Instruments}

Data consisted of six audio files from six seminar discussion sessions held at different points in time during the semester. It also included individual students' seminar plans, and seminar mapping for each session. I made sure that the samples represented different moments in time, so as to track the improvement of argumentation throughout the semester. Two of the samples correspond to seminars held at the beginning of the course, two were held towards the middle of the semester, and two at the end.

Discussion texts are a core component of successful Paideia Seminars. A good text is usually ambiguous and challenging both in terms of content and language. Quality literary texts can foster argumentation and dialogic reasoning if they deal with issues that are of participants' interest, and if these ideas are presented from multiple perspectives. In terms of ideas and values (Adler, 1998), the selected short stories deal with the topics of love, human relationships, making choices, and maturity, all of which are typically relevant to young adults. Language complexity and richness can also foster argumentation, as it allows for multiple interpretations and connotations. These criteria were used in the selection of the stories that students were required to read and discuss in the current study, with the exception of the Greek myth Cupid and Psyche, which is an anonymous, so the version is an adaptation.

\section{Data Analysis and Interpretation}

Transcripts were parsed into statements as units of analysis (Whaley, 1981). To determine where each transcript began, I decided that the first statement in the transcript would be the facilitator's first opening question. The last statement on each transcript was the statement prior to the facilitator's prompt to close the seminar discussion, or the instructions given to students for their post-seminar activity. 
Coding of maieutic frames. The first step in the coding process was to identify the first open-ended question in the transcript, to signal the beginning of a maieutic frame. Questions had to a) initiate a discussion, b) set the stage for topic exploration from various viewpoints, c) have more than one right answer, or, d) add rigor to the discussion. These open-ended questions were labeled "maieutic questions."

Next, I examined every statement between each maieutic question, and coded it for the other two maieutic features: 1) elaboration of ideas and 2) inductive and exploratory talk. Evidence of elaboration of ideas might include the presence of a. textual references (TR), b. connection across texts (CT), or c. elaboration using prior knowledge or experience (PK). Evidence of inductive and exploratory talk included one or more of the following: a. interpretation (IN), b. explanation (EX), c. diverging idea (DI) or d. new understanding (NU).

After statements were coded, I identified the end of a maieutic frame, which was signaled by either a new open-ended question, a change in the discussion topic, or a drastic change in participation structure; for example, if participants who had not spoken before entered the discussion (Stubbs, 1983).

To be considered a maieutic frame, a frame had to include: 1. an open-ended maieutic question that triggered the discussion, 2. at least one indication of elaboration of ideas (at least one TR, CT, or PK), and 3 . at least one evidence of inductive and/or exploratory talk (at least one IN, EX, DI, or NU). Figure 1 summarizes the above-mentioned components.

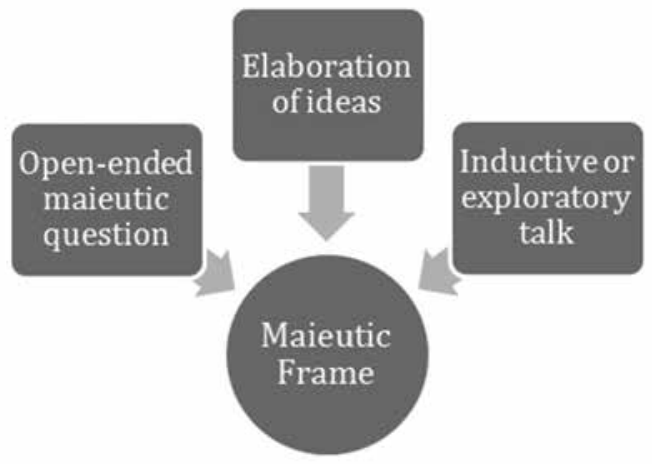

Figure 1. Components of a maieutic frame. 
Once maieutic frames were identified, they were numbered on a coding sheet. The same procedures were conducted for each transcript. In four of the six seminar transcripts I identified nine maieutic frames, whereas two of the transcripts contained ten frames. The average of frames per transcript is 9.33 .

Coding of argumentation. Each transcript was also coded for presence of argumentation. First, I examined every statement in the protocol to determine which ones were claims for possible arguments. A claim could be an assertion, the establishment of a fact, a proposition, or something that the speaker wanted to prove.

Second, I examined the statements following the claim and coded them as either "data," "warrant," "backing," "qualifier," "rebuttal," or null (ø) if they did not fall into any of the categories. A statement was considered data and coded as such if it provided information, facts, or grounds to support the claim (Toulmin, 1958). A statement was coded as "warrant" if it functioned as a link between the claim and the data. Warrants are hypothetical statements that asserted that there was a reasonable or logical relationship between the claim and the data (Toulmin, 1958). A statement functioned as backing and was coded as such if it was an additional assurance to the warrant. A statement was coded as a qualifier if it established conditions under which the claim was supported by the data, or determined the relative strength of an argument. Statements that function as qualifiers contain adverbs of degree such as generally, usually, seldom, probably, presumably, etc. Finally, a statement was considered a rebuttal and was coded as such, if it was an objection to the claim, or if it presented circumstances under which the claim would not be held true.

Third, after all statements were coded, I determined the beginning and the end of an argument. The beginning of an argument was marked by the claim that started each argument in a transcript. The end of an argument was marked by a claim that brought about a new argument, i.e., a claim that introduced a new topic, or a rebuttal that initiated a new argument. An argument could also end with a concession of the claim - the acceptance of the argument's feasibility.

Fourth, after arguments and their components were identified, they were numbered on the coding sheet. Procedures 1 to 4 were conducted for each of the transcripts.

Coding of quality of argumentation. After each statement in an argument had been labeled according to its function in the discourse, I examined each argument and assigned each of them a quality level, using Osborne, Erduran, and Simon's (2004) analytical framework for 
assessing the quality of argumentation. The framework contains five quality levels based on the type and amount of argument components found in each argument. For example, an argument that contained a single claim and a counterclaim, with no additional grounds (data, warrants, backings), would be a level 1 argument in the framework by Osborne et al., and would be labeled as such. On the other hand, an argument that contained more than one claim, several ground sources, and more than one rebuttal would be considered a level 5 argument and would be labeled as such. Thus, each argument was labeled as level $1,2,3,4$, or 5 , with 1 being the lowest quality level, and 5 being the highest quality level. Table 1 illustrates the coding categories for argumentation.

Table 1. Argumentation coding categories (adapted from Osborne, Erduran, \& Simon, 2002)

\begin{tabular}{|l|l|}
\hline Level & Argument description \\
\hline 1 & $\begin{array}{l}\text { Arguments containing one claim and one counter claim or } \\
\text { two simple claims }\end{array}$ \\
\hline 2 & $\begin{array}{l}\text { Arguments containing more than one claim plus data, } \\
\text { warrants or backings, but no rebuttals }\end{array}$ \\
\hline 3 & $\begin{array}{l}\text { Arguments containing several claims and counter claims } \\
\text { with data, warrants or backings and one or more weak } \\
\text { rebuttal }\end{array}$ \\
\hline 4 & $\begin{array}{l}\text { Arguments containing a claim with a clearly identifiable } \\
\text { rebuttal, and, but not necessarily, additional claims and } \\
\text { counter claims }\end{array}$ \\
\hline 5 & $\begin{array}{l}\text { Arguments which are extended and contain several } \\
\text { rebuttals }\end{array}$ \\
\hline
\end{tabular}

Inter-coder reliabilities were acceptable for transcript parsing into statements, identification of maieutic frames in each transcript, as well as for number of arguments and their quality. On average, each transcript in the current study contained 3.75 arguments per 100 statements, ranging between 2.50 and 5.34 arguments per 100 statements. In terms of quality, the arguments were given an average of 2.70 , with values ranging between 2.05 and 3.8 . 
To examine the potential association between number of maieutic frames and quantity and quality of argumentation in each seminar transcript, correlational analyses were conducted. Prior to that, data was examined using descriptive analyses. Non-parametric correlations (Spearman's rho) were used to determine magnitude and direction of correlations.

\section{Results}

As was previously mentioned, on average, seminars contained 9.33 maieutic frames in total, which means that there was, on average, .324 maieutic frames every 100 statements. On the other hand, the average number of arguments per 100 statements was 3.6, with values ranging between 2.50 and 5.34. In order to determine whether the variable distributions and relationships performed in expected ways, descriptive values were analyzed. Table 2 displays the means, standard deviations, and values for the selected variables, for each of the six transcripts.

Table 2. Descriptive statistics

\begin{tabular}{|l|c|c|c|c|c|c|c|c|}
\hline \multicolumn{1}{|c|}{ Seminar } & 1 & 2 & 3 & 4 & 5 & 6 & Mean & SD \\
\hline $\begin{array}{l}\text { No. } \\
\text { Statements }\end{array}$ & 237 & 267 & 244 & 261 & 353 & 187 & 272.4 & 46.678 \\
\hline $\begin{array}{l}\text { No. } \\
\text { Maieutic } \\
\text { Frames } \\
\text { per 100 } \\
\text { Statements }\end{array}$ & .35 & .33 & .32 & .38 & .32 & .33 & .324 & .0522 \\
\hline $\begin{array}{l}\text { No. } \\
\text { Arguments } \\
\text { per 100 } \\
\text { Statements }\end{array}$ & 3.79 & 3.37 & 3.68 & 3.83 & 5.34 & 2.50 & 3.6 & 5.568 \\
\hline $\begin{array}{l}\text { Argument } \\
\text { Quality } \\
\text { Average }\end{array}$ & 2.09 & 2.05 & 2.7 & 2.43 & 3.1 & 3.8 & 2.47 & .439 \\
\hline
\end{tabular}

\section{Number of Maieutic Frames per 100 Statements}

It would be expected that, if students had mastered seminar facilitation at more or less similar levels, and if seminars were of a similar time length, seminar transcripts would exhibit similar number of frames per statements. Results show that the number of maieutic frames per 100 statements in the selected transcripts ranged between .32 and .38 , with a difference of only .05 , so in general, it could be inferred that the number of maieutic frames that emerged in each seminar was fairly similar, and thus transcripts are comparable. 
On the basis of previous transcript analyses (e.g., Author, 2008), a second expectation would be that seminars about more complex texts would elicit more maieutic frames than those where language is less sophisticated and ideas are not as complex. This would be especially true of Paideia seminars where authentic texts, such as philosophical or historical documents tend to facilitate the occurrence of cognitively productive talk among participants, because of linguistic sophistication and intellectual challenge (Adler, 1984). Of the six seminar texts (short stories), "Hills Like White Elephants", by Ernest Hemingway, "The Secret Miracle" by Jorge Luis Borges, "The Lady or the Tiger?" by Frank Stockton, and "Appointment with Love" by S.I. Kishor, are all original texts; that is, they are not adapted versions as would be the case of "Jack and the Beanstalk" and "Cupid and Psyche." Table 3 displays the selected transcripts, in the order in which they took place during the semester, and the values for each of the variables. It can be observed that, in terms of number of maieutic frames, the seminars with a higher number of frames and number of arguments are "The Secret Miracle" and "The Lady or the Tiger?" However, when one looks at argument quality, the highest quality can be observed in the transcripts from "Appointment with Love" and "The Lady or the Tiger?" In both cases, that is, seminars with the highest numbers of maieutic frames as well as with the highest argument quality levels, unabridged versions were more productive in terms of number of frames and argument quality. This finding ratifies Adler's belief that quality texts produce quality discussions (Adler, 1984; Author, 2008).

Table 3. Selected variable distribution for each seminar transcript.

\begin{tabular}{|l|c|c|c|}
\hline \multicolumn{1}{|c|}{ Transcript } & $\begin{array}{c}\mathrm{N}^{\circ} \text { of Maieutic } \\
\text { Frames per 100 } \\
\text { Statements }\end{array}$ & $\begin{array}{c}\mathrm{N}^{\circ} \text { of Arguments } \\
\text { per 100 } \\
\text { Statements }\end{array}$ & $\begin{array}{c}\text { Argument } \\
\text { Quality }\end{array}$ \\
\hline 1. Jack and the Beanstalk & .37 & 3.79 & 2.09 \\
\hline 2. Hills like white Elephants & .33 & 3.37 & 2.05 \\
\hline 3. Cupid and Pysche & .36 & 3.68 & 2.7 \\
\hline 4. The Secret Miracle & .38 & 3.83 & 2.47 \\
\hline 5. The Lady or the Tiger? & .53 & 5.34 & 3.8 \\
\hline 6. Appointment with Love & .25 & 2.50 & 3.1 \\
\hline
\end{tabular}

\section{Associations beween Degree of Maieutic Presence and Degree of Quantity and Quality of Argumentation}

In order to determine the potential associations between number of maieutic frames and quantity and quality of argumentation in each seminar transcript, non-parametric correlational analyses between the 
three variables were conducted, looking at the rank order of the scores in each variable. For Number of Maieutic Frames per 100 Statements and Number of Arguments per 100 Statements the correlation was .873. A highly positive correlation was also observed between Argument Quality and Number of Arguments per 100 Statements (.624), which seems to indicate that, as the number of arguments increases, so does the quality of such arguments. However, the correlation between Argument Quality and Number of Maieutic Frames per 100 Statements was only .285. Post-hoc tests were conducted to confirm that test distribution was normal.

To determine whether maieutic frame presence and increase in argument quality were related, we conducted correlational analyses. Spearman correlations confirmed the assumption that seminars where more maieutic frames were observed also displayed more arguments per 100 statements, and that the quality of those arguments was of a higher degree than that of arguments in seminars with fewer maieutic frames. This positive relationship can be explored in more detail using examples of how argument quality unfolds in transcripts with more versus those with fewer maieutic frames.

The analyses and interpretations allow us to state that presence of more maieutic frames in a seminar discussion is positively associated with increased amount of quantity and quality of argument development on the part of the students. We have also noticed that there also seems to be a positive correlation between text type and argument quantity and quality, and that certain text features, such as their degree of ambiguity and lexical complexity, seem to foster or hinder the rate at which these arguments emerge, as well as their quality. This finding has important implications for pre- and in-service teachers in terms of choosing more complex texts for classroom discussion, especially if the purpose is to set a terrain fit for the development of higher order thinking skills.

The following excerpt from "The Lady or the Tiger?" is an example of a discussion containing more maieutic frames and more arguments per 100 statements, in which the quality of argumentation is also higher. The excerpts that will be used for the purposes of exemplifying argument quality (both high and low) are all part of one maieutic frame, in which 14 arguments were identified. The number in parentheses following each identified argument indicates the quality assigned to each argument.

Facilitator: What do you think about the king's method of administering justice? 
Student 1: I don't think it was not, I'm not sure if the reading... if it was really clear or not, the trial itself, Because how he conveyed it, how he said it, somewhere it said that it could never be wrong so we don't really know, I mean, If it could never be wrong, then it must be fair. (3)

Student 2: And also, at that time in history it did't say what time it was, but there was an arena, maybe people believed more in fate than we do nowadays, so they say it's up to fate, so for nowadays maybe it's not fair. So if he says so, he'd open the door. (4)

Student 3: Nowadays I would say it's not fair because it's a matter of love, but in those days when people believed more in destiny and being predetermined about what was bound to happen in your life, I believe it was fair because, for them, what was bound to happen would happen. (4)

In the previous excerpt, because the story does not provide much specific information regarding the historical and/or sociocultural context of the events, students rely on their knowledge of ways of life and beliefs that people who presumably lived in a semi barbaric period must have had. In this sense, they assume that fate or predetermination might have been a common belief, and that therefore, the characters may have accepted their luck on the basis of predetermination. On the basis of such premise, then, the kings' ways of administering justice do not seem out of place.

Students also use textual references to support their views, and tend to agree that the king's method of administering justice is fair given the context. Here students have used their historical background knowledge to interpret the events in the story without getting into the moral dimensions of the dilemma, except for student 6 who later brings in the fact that the trial was not fair because the accused did not have a chance to defend himself:

Facilitator: I'd like to go back to what the people were saying about is it because it's right that it's fair? What do you think?

Student 4: I have one on the first page, it says, "this was the king's semi barbaric method of administering justice its perfect fairness is obvious, because the criminal could not know..."

Student 4: So maybe like Student 3 said, in those days, fate was very important, so they believed that the door that the thief would open would be the right one for his fate. (3)

Facilitator: So here we're thinking fair equals fate, whatever fate says is fair, and therefore right?

Student 5: And also if it was wrong, it says that in its perfect fairness the person would not know which door is the one with the lady, So in that 
sense I think that it could be fair because the supposed criminal doesn't have a way to cheat the jury. (4)

Student 4: And yes, then it says the decision of this criminal was not only fair; they, they were positively determined, the guilty person was instantly punished. And (if he was) innocent, he was rewarded of his fault.

Facilitator: Hmm, and how do you think that the king demonstrated he's a semi barbaric king?

Student 2: I was impressed by the way that either the idea or the author was to put this opposite of two extremes, like one extreme was to be eaten by a tiger and to die, right? And the other extreme was like happiness with a woman; that's, I mean, because you may say, sadness or happiness could be on either door, but they compared the exchange and happiness with a woman, even if they were married, so I think that was barbaric also, maybe the personality was like extremist, and I would really think that if (inaudible) I don't know if anybody else realized that. (5)

Student 2: and also they are extremes, but if you look at it, since it says in the text that even if the man was married or had children, he would have to marry the girl, so that may also be a punishment, So it's not always a reward. (4)

Student 4: You were obliged to what he said, 'cause nowadays if you, like, the prize you can use it, or if you don't, you can return it, but if you win the woman you have to marry her, even if one of the two doesn't want to. (4)

The above excerpts are all examples of student reasoning supported by textual references, elaborating on each other's thinking and extending talk as they explore ideas beyond the literal. It is possible to see that overall argument quality is high and that there is some evidence of looking at issues from more than one viewpoint. The next excerpt was taken from the discussion of "Jack and the Beanstalk", the first seminar that the students engaged in. For comparison purposes, we have selected one maieutic frame, which illustrates weak argumentation quality:

Facilitator: Several of you have said that he (Jack) was ambitious as a characteristic, right? but, where exactly in the text do you, because, does the narrator really tell us that he was ambitious?

All: No

Student 1: He repeatedly goes up the beanstalk to find more and more...

Student 1: ...to steal things he goes back and then he goes again. It never says, maybe I don't know he wants to get more money to help his family, 
or to get the things back from his father. It never gives a reason, so that's why (2)

Student 2: All he says is that he's got the bag of coins. It never says anything else, it never gives a reason, it just says that. (2)

While it is true that the text does not literally say that Jack was ambitious, in this discussion excerpt we can see students attempting to justify a character trait that is easily drawn from the story text. Their choice of trait — ambition — does in fact characterize Jack; yet, in trying to explain how this is true for the character, they move between speculation about text meaning, and hypothetical situations. Students also tend to bend more towards rather "expected" interpretations of characters' actions, such as stealing to feed Jack's mother, which prevent participants from moving beyond the text. This conversation feature is also observable in the third discussion session ("Cupid and Psyche"), a text that, like "Jack and the Beanstalk", seemed to be too self-contained and unambiguous and thus prevented discussion from moving into deeper thinking and argumentation.

Another aspect worth analyzing is the extent to which opportunity to acquire expertise in discussion facilitation plays a key role in the acquisition of such skill. The pre-service teachers in this study showed a significant improvement in their mastery of seminar facilitation, and this was evidenced in their ability to gradually make more sophisticated contributions and seminar questions. They also showed considerable improvement in their seminar participation, both at becoming more expert in finding evidence and presenting it in a convincing way, as well as providing higher-quality rebuttals to build new arguments. In a similar way, one would expect students to improve their argumentative ability as a result of continuous exposure to opportunities to participate in highly intellectual discussions. With careful scaffolding, students should gradually gain the expertise needed to scrutinize texts more critically in order to construct high-quality arguments.

Along with classroom opportunities, an even greater challenge is to prepare teachers to become skilled facilitators, regardless of the discussion method that is used. Preparation implies not just formal understanding about the procedures of any dialogic discussion format, but ideally, a personal experimentation of various ways of doing discussion. Unfortunately, few teacher education programs provide preparation in this area, and most teachers become familiar with dialogic approaches to learning after they have spent several years in the profession. 


\section{Conclusions}

The current study examined the development of argument quantity and quality among pre-service teachers enrolled in a literature course by means of facilitating Paideia Seminars. Results showed that as argument quantity increased so did quality. It was also possible to observe that as students became more experienced participants of seminars, the quality and quantity of argumentation in the seminars also increased. Finally, from a more qualitative perspective, we were able to determine that certain text features such as their complexity and ambiguity did, in fact, contribute to the improvement of argument quantity and quality. These results point to the usefulness of seminars as a pedagogical tool to help pre-service teachers develop their own thinking skills and, by acquiring expertise in seminar facilitation, implement this technique with their future students.

It is also necessary to acknowledge some of the limitations of the study. First, the small number of seminars included in the analyses prevents us from generalizing findings. Second, a larger sample of transcripts from discussions held by pre-service teachers across different programs and/or universities would provide richer results by comparing argument structure, frequency, and quality across different populations. From a practical perspective, another limitation was the fact that of all 16 transcripts only six were used because the audio quality of ten of the recordings did not allow proper transcription.

Besides establishing the interrelationship between argument quantity, quality, and text complexity, the current study has shown that the maieutic frame as a construct can allow us to examine argumentation from a more quantitative standpoint, and by doing so, to explore how it can be incremented with the proper conditions. By exploring argumentation in discussion segments that are framed by specific features such as the ones that define the maieutic frame, it is possible to identify associations between features and argument components that shape the amount and quantity of arguments in talk. Future studies should extend these analyses in ways that help us better understand how thinking can be enriched in discussion settings and how teachers can contribute to its improvement.

Argumentative skills and the ability to think critically about knowledge and the world are much-desired educational objectives. As can be drawn from evidence, the attainment of these abilities is not solely dependent on curriculum content and material, but especially on the existence of classroom instruction instances that force students to use higher order thinking skills, and the presence of models that 
exemplify the use of arguments in discourse. Teachers can demonstrate the use of quality argument development if they have acquired such skills and if they can identify instances for students to engage in rich argumentative discussions. The dynamic relationship between student thinking, text complexity and rigorous questions is important to note.

Teacher education programs need to address and encourage argument development among pre-service teachers by making them familiar with instructional techniques and contexts that facilitate argument production, and also by constantly monitoring their participation in argumentative discourse. In the current study, we have shown how, by using Paideia Seminars for classroom discussion, teachers not only learned to facilitate seminar discussions, but also had the opportunity to improve their argumentative abilities. Future teachers learned that argument quality can be tracked and improved by carefully selecting material and planning questions that trigger cognitive conflicts (Almasi, 1995). The use of Paideia Seminars in courses that foster dialogic participation, careful reading and interpretation, can facilitate the development of higher order thinking skills, while at the same time allow teachers to use the maieutic frame as a tool to explore and monitor argument quality. In this way, pre-service teachers learn to understand how argumentative discourse unfolds, how quality arguments can be identified, and how productive discussion contexts can be created. 


\section{References}

Adler, M. (1984). The Paideia program: An educational syllabus. New York: Institute for Philosophical Research.

Adler, M. (1998). The Paideia proposal. New York: Touchstone Books.

Allington, R. (2002). Big brother and the national reading curriculum: How ideology trumped evidence. Portsmouth, NH: Heinemann.

Almasi, J. (1995). The nature of fourth graders' sociocognitive conflicts in peer-led and teacher-led discussions of literature. Reading Research Quarterly, 30(3), 314-351.

Anderson, R. C., Nguyen-Jahiel, K., McNurlen, B., Archodidou, A., Kim, S.-Y., Reznitskaya, A., Tillmans, M.,\& Gilbert, L.(2001). The snowball phenomenon: Spread of ways of talking and ways of thinking across groups of children. Cognition and Instruction, 19, $1-46$.

Billings, L. \& Roberts, T., (2006). Planning, practice, and assessment in the seminar classroom. The High School Journal, 90(1), 1-8.

Carbonaro, W. J., \& Gamoran, A. (2002). The production of achievement inequality in high school English. American Educational Research Journal, 39, 801-827.

Cazden, C. (1988). Classroom discourse: The language of teaching and learning. Portsmouth, NH: Heinemann.

Chinn, C., Anderson, R. C., \& Waggoner, M., (2001). Patterns of discourse during two kinds of literature discussion. Reading Research Quarterly, 36, 378-411.

Darling-Hammond, L., (2006). Powerful teacher education. Lessons from exemplary programs. San Francisco, CA: Jossey-Bass.

Ferretti, R. P., Andrews-Weckerly, S., \& Lewis, E. W. (2009). Do goals affect the structure of students' argumenatitve writing strategies? Journal of Educational Psychology, 107(3), 577-589.

Gillies, R., \& Khan, A., (2009). Promoting reasoned argumentation, problem-solving, and learning during small-group work. Cambridge Journal of Education, 39(1), 7-29.

Goldstein, M., Crowell, A., \& Kuhn, D., (2009). What constitutes skilled argumentation and how does it develop? Informal Logic, 29(4), 379-395.

Haroutunian-Gordon, S. (1991). Turning the soul. Chicago: University of Chicago Press. 
Kim, I.H., Anderson, R.C., Nguyen-Jahiel, K., Archodidou, A., (2007). Discourse patterns during children's collaborative online discussions. Journal of the Learning Sciences, 16(3), 333-370.

Kuhn, D., and Udell, W.,(2003). The Skills of Argument. Child Development, 74(5), 1245-1260.

Kuhn, D. (2011). Shared standards of knowledge. Teaching and learning science as argument. Science Education, 94, 810-824.

Lazarou, A. (2009). Learning to tap: an effort to scaffold students' argumentation in science. Paper presented at the European Science Education Research Association Conference. Istambul, Turkey, 2009.

Leitao, S. (2003). Evaluating and selecting counterarguments: Studies of children's rhetorical awareness. Written Communication, 20(3), 269-306.

Lin, H., (2012). Promoting and scaffolding argumentation through reflective asynchronous discussions. Computers and Education, 59(2), 378-384.

Maloney, J. \& Simon, S., (2006). Mapping children's discussion of evidence in science to assess collaboration and argumentation. International Journal of Science Education, 28(15), 1817-1841.

McCann, T. M. (1989). Student argumentative writing: knowledge and ability at three grade levels. Research in the Teaching of English, 23, 62-76.

Means, M. and Voss, J., (1996). Who reasons well? Two studies of informal reasoning among children of different grade, ability, and knowledge levels. Cognition and Instruction, 14(2), 139-178.

Mercer, N. (2011). Reasoning serves argumentation in children. Cognitive Development, 26(3), 177-191.

NAEP, (2002). The nation's report card: Reading 2002. Retrieved from: http://nces.ed.gov/nationsreportcard/pdf/main2002/2003521.pdf.

Noguera, P. \& Cohen, R. (2006). Patriotism and accountability: The role of educators in the war on terrorism. Phi Delta Kappan, 87(8), 573-578.

Nussbaum, M. E. \& Kardash, C. M. (2005). The effects of goal instructions and text on the generation of counterarguments during writing. Journal of Educational Psychology, 97(2), 157-169. 
Nystrand, M., Gamoran, A., Kachur, R., \& Pendergast, C. (1997). Opening dialogue. Understanding the dynamics of language and learning in the English classroom. New York: Teachers College Press.

Nystrand, M., Gamoran, A., \& Carbonaro, W. (2001). On the ecology of classroom instruction: The case of writing in high school English and social studies. In P. Tynjälä, L. Mason, \& K. Londa (Eds.), Writing as a learning tool (pp. 57-81). Dordrecht, the Netherlands: Kluwer Academic Publishers.

Nystrand, M., Wu, L., Gamoran, A,, Zeiser, S., \& Long, D. (2003). Questions in time: Investigating the structure and dynamics of unfolding classroom discourse. Discourse Processes, 35, 135-196.

Nystrand, M., (2006). Research on the role of classroom discourse as it affects reading comprehension. Research in the Teaching of English, 40, 392-412.

Orellana, P. (2008). Maieutic frame presence and degree of quantity and quality of argumentation in a Paideia Seminar. Unpublished doctoral dissertation. The University of North Carolina at Chapel Hill.

Osborne, J., Erduran, S., and Simon, S., (2002). Enhancing the quality of argumentation in science classrooms. Journal of Research in Science Teaching, 4(10), 994-1020.

Pedrosa-de-Jesús, H., Silva, B., Moreira, A., \& Watts, M., (2012). Higher education challenges to teach argumentation. Higher Education, 64(4), 557-571.

Reznitskaya, A., Anderson, R. C., McNurlen, B., Nguyen-Jahiel, K., Archodidou, A, \& Kim, S., (2001). Influence of oral discussion on written argument. Discourse Processes, 32(2\&3), 155-175.

Reznitskaya, A., Anderson, R., \& Kuo, L., (2007). Teaching and learning argumentation. The Elementary School Journal, 107(5), 450-472.

Reznitskaya, A. \& Anderson, R., (2006). Analyzing argumentation in rich, natural contexts. Informal Logic, 26(2), 175-198.

Rojas-Drummond, S. \& Mercer, N., (2003). Scaffolding the development of effective collaboration and learning. International Journal of Education, 39, 99-111.

Rojas-Drummond \& Zaparta, M., (2004). Exploratory talk, argumentation and reasoning in Mexican primary school children. Language and Education, 18, 109-117. 
Shulman, L., (1986). Paradigms and research programs in the study of teaching. In M. C. Wittrock (Ed.), Handbook of research on teaching. (pp. 3-36 ) New York: MacMillan.

Simon, S., Erduran, S., \& Osborne, J., (2002). Enhancing the quality of argumentation in school science education. Paper presented at the Annual Meeting of the National Association for Research in Science Teaching, April 7-10, 2002 New Orleans, USA.

Stubbs, M., (1983). Discourse analysis. The Sociolinguistic analysis of natural language. Worcester, U.K.: The University of Chicago Press.

Toulmin, S., (1958). The uses of argument. London: Cambridge University Press.

Van Eemeren, F. H., Grootendorst, R. \& Snoeck Henkemans, F. (1996). Fundamentals of argumentation theory: A handbook of historical backgrounds and contemporary developments. Mahwah, NJ: Erlbaum.

Voss, J. F., \& Van Dyke, J. A. (2001). Argumentation in psychology: Background comments. Discourse Processes, 32(2\&3), 89-111

Walzer, M., (2004). Politics and passion: Toward a more egalitarian liberalism. New Haven, CT: Yale University Press.

Whaley, J. F., (1981). Story grammars and reading instruction. The Reading Teacher, 34, 762-771.

Author

*Pelusa Orellana holds a PhD in Education from the University of North Carolina in Chapel Hill. She has been Dean of the School of Education for nearly 12 years and currently holds the position as Associate Dean for Research. Her areas of research are reading diagnosis, reading assessment and motivation, where she currently works on two grants, one investigating the connection between reading motivation and achievement differences between boys and girls (grades 3-5), and the other determining the norms for reading sub-processes in Chilean students based on a reading diagnosis assessment platform she has developed. 